\title{
Promoting Tourism Investment in Emerging Destinations: Exploring Challenges and Opportunities: Evidences from Amhara Region, Ethiopia
}

\author{
Yihalem Kebete, MA, \\ Department of Hotel and Tourism Management, Bahir Dar University, Bahir Dar
}

\begin{abstract}
The current study examined challenges and opportunities of tourism investment through the lenses of Porter's five forces industry analysis. This study pursued an exploratory research design with qualitative approach. Academicians, travel agents, tour operators, hotel business owners and government tourism bureau experts were the main participants of the study. Findings of the current study unveil that inadequate infrastructure and mischief land use policy demise the growth of tourism investment in the study area. However, import duty-free policy for tourism investment and availability of copious tourism resources coupled with support from credit providing institutions embolden tourism investments in Amhara region.
\end{abstract}

Keywords: Amhara Region, Challenges, Emerging destinations, opportunities, Tourism investment.

DOI: $10.7176 / \mathrm{JTHS} / 57-01$

Publication date:June $30^{\text {th }} 2021$

\section{Introduction}

As one of the world's principal industries, tourism has grown rapidly and continuously for the last four decades and has become a renowned source of global employment (UNWTO, 2018). Tourism is a dynamic industry comprising highly fragmented business entities such as travel organizers, accommodation providers, transport services and attractions (Kebete \& Wondirad, 2019; Wondirad, 2019; Worku \& Tesema 2018). The field of tourism has keen investment opportunities that call many investors with immense benefits (Rasul \& Manandhar, 2009). Hence, investing in tourism is quite substantive to enhance the socio-economic advancement of a particular nation with tremendous tourism resources (Montero, 2011). Evidently, tourism is one of the most lucrative businesses that capacitate the multiplier effects of tourism (Page \& Connell 2006; Ajaala 2007; Spencelery \& Meyer, 2012; Timoty 2016). Africa has plentiful resources encompassing multiple cultural heritages and historic features that are offered to the world (Saarinn \& Rogerson, 2014). The continent of Africa comprises a range of emerging tourism destinations such as Congo, Tunisia, Kenya, South Africa and Mauritius that played a fundamental role in fostering the economic advancement of the continent (Signe, 2018). As long as Africa is a home to a number of young populations, tourism investment would serve as a springboard in fostering future economic advancement of tourist destinations (Signe, 2018). This is due to the fact that tourism investment requires young workforces. Hence, investing in tourism would be profoundly important to create new jobs to the youth in Africa. In addition, tourism has long been considered as a way of enhancing peace among nations (UNWTO, 2018). For instance, Eritreans and Ethiopians have not been visiting each other's country for almost two decades. However, in 2018 Ethiopian and Eritrean governments signed a peace agreement to cooperate each other in peace keeping activities. Hence, both citizens have been allowed visiting tourist sites found in Eritrea and Ethiopia since 2018. Due to this reason, now both countries are in good relation that enables the free movement of their citizens.

Even though private sectors primarily sustain tourism activities, government has also played a crucial role for the development of tourism industry at policy level (Butler, 1990). In fact, governments in developing economies should encourage tourism investments (Reid, 2003). For instance, as Ethiopia experiences developing economies, investors are encouraged to invest in tourism and hospitality sectors. Tourism investment allows Ethiopia to properly utilize its immense tourism resources. On the other hand, tourism has higher multiplier effects in developing regions as compared to other sectors such as agriculture and mining (Archer \& Owen, 1971; Rasul \& Manandhar, 2009; Roe, Ashley, Page \& Meyer, 2004; Peris-Ortiz, 2016). Regarding the foreign investment policy of Ethiopia, tourism has been one of the most neglected economic sectors for long (ANRSCTB, 2017). However, some domestic investors such as Haile Gebresellassie Hotel business, Kuriftu Resort and Spa, Star Business group and Grand resort and Spa businesses have invested their money especially on large hotels, tour and travel companies, speciality and traditional restaurants.

However, an extensive review of extant literatures in tourism investment unveil that this area has received inadequate attention by the research communities and negligible research has been found on public and private tourism investment opportunities and challenges ( World Economic Forum). Hence, there is an immediate need to conduct research with respect to opportunities and main challenges of tourism investment in Amhara region. Subsequently, the present study aims to: 1) Analyse tourism investments in Amhara region through the lenses of Porter's five industry force analysis, (2) Investigate the major opportunities of tourism investment in Amhara 
region and (3) examine the main challenges of tourism investment in the study area.

\section{Literature review}

\subsection{Tourism investment}

Tourism investment is increasingly viewed as a prominent tool in promoting economic growth. Investing in tourism and hospitality is vital to mitigate problems related to poverty and secure food in developing countries (Magole \& Magole, 2011; UNDP, 2011). Thus, exploring how investments in tourism should contribute to the economic development of developing regions would be paramount (Mbaiwa 2005; Rogerson \& Rogerson, 2011; UNWTO, 2018). Numerous studies have demonstrated that tourism can play a significant role in balancing sustainable development within developing regions (UNCTAD, 2017; UNWTO, 2018). Several strategies for tourism development are imperative in creating employment and generating income for vulnerable groups and communities (UNWTO, 2000; Ashley, Roe \& Goodwin, 2000; UNDP 2011; Boesen et al., 2017).

Despite its immense potentials, the continent of Africa was not in a good position to attract many investors in the field of tourism (AfDB, 2016a). Distinctly, African countries such as Ethiopia, Kenya, South Africa and Morocco have untapped tourism potentials (Rogerson \& Van der Merwe, 2016; Adu-Ampong, 2017). Hence, most countries in Africa have already drafted strategic plans to develop tourism (AfDB, 2016a; Federal Democratic Republic of Ethiopian Ministry of Culture and Tourism, 2017; ANRSCT, 2018). Among African countries, Gambia, Kenya, South Africa, and Tanzania have been striving a lot in fostering travel and tourism development for long (UNWTO, 2016). In a similar vein, Botswana, Mauritius, Rwanda, and South Africa are performing a robust work to provide an enabling environment for tourism and hospitality investments (UNWTO, 2018).

Overall, conferring tendencies, drivers, perceptions, and policies for tourism investment in Africa receives greater emphasis (World Economic Forum 2017; UNCTAD, 2017). As a result, tourism investment has become a prime economic agenda in most regions especially in Eastern African countries. Besides, governments should do strong tasks to attract more investments given the potential that the continent holds (World Bank, 2014; ECOWAS, 2018; UNCTAD 2017; Adu-Ampong 2017). Each stakeholder in tourism should have to undertake an important activity in improving tourism investment in Africa (Wonderad, 2019; Scherle 2011). Accordingly, the tourism resource inventory system would permit countries to know what resources are available and devise appropriate marketing strategies for each tourism product (Signe, 2018). However, most African countries especially Ethiopia, Eriterea and Sudan did not properly practice tourism resource inventory system thereby hold back tourism activities in east Africa (Adu-Ampong, 2017).

\subsection{Porter's five force industry analysis}

Porter's five force industry analysis is substantive to understand the status of existing tourism investment opportunities and challenges in tourist receiving areas (Dobrivojević, 2013).The author suggest that Porter's five forces would be used to measure competition intensity, attractiveness, and profitability of tourism and hospitality industry in Amhara region. Porter's five force analysis is prominent to dig out major opportunities and challenges in tourism and hospitality investments (Signe, 2018). It is vital to decide the procedure of business organizations and the level of competition among investors within a particular sector. In a similar vein, tourism investments in certain destinations such as Europe and North American countries experience stiff competition among investors (Poon, 1993). Thus, it is a real challenge for new tourism investments in highly developed tourist destinations (Poon, 1989).

\section{The study area}

\subsection{Amhara region}

Amhara region is one of the10 ethnic divisions of Ethiopia, containing the homeland of the Amhara people. Amhara region is bordered by the state of Sudan to the west and northwest, and in other directions by other regions of Ethiopia: Tigray to the north, Afar to the east, Benshangul- Gumez to the west and southwest, and Oromia to the south. Amhara region has heterogeneous endemic species of fauna including the Gelada Baboon, the Walia Ibex and the Ethiopian Wolf (or Simien fox). Above and beyond, in Amhara region, there are wide variety of spectacular tourist attractions such as Lake Tana with its peninsula and island monasteries and aquatic animals \& birds. Blue Nile fall (TisIsat) is also one of the most impressive tourist sites found in Amhara region. The Blue Nile Fall is a waterfall on the Blue Nile River in Ethiopia. The fall is one of Ethiopia's best known tourist attractions (ANRSCTB, 2018). 


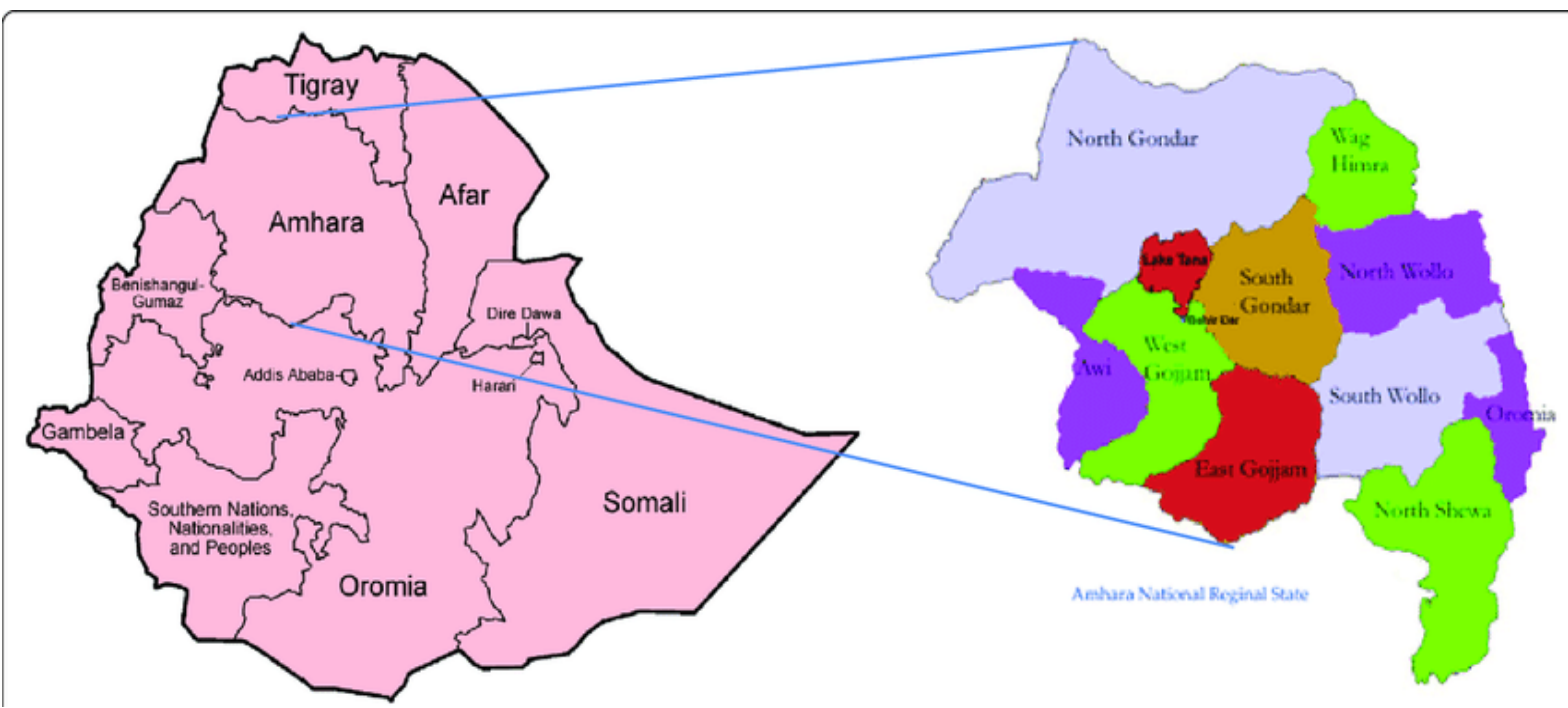

Fig.1 Map of Amhara region (www.amhararegion.com)

\subsection{Research method}

The present study explores fundamental issues with respect to challenges and opportunities of tourism investment in Amhara region. As a result, the author followed the techniques of exploratory research design and qualitative research approach. Purposive and snowball sampling techniques have been used to select key informants working in the field of tourism and hospitality. Data required for the study have been collected from both primary and secondary sources. The secondary data were sourced from the published and unpublished records of Bureau of Culture and Tourism in Amhara region. Interview and focus group discussion were the major data collection tools used to collect data relevant for the study. 27 purposively selected key informants were interviewed in the study area. The researcher has prepared 36 interview questions. Interviews conducted in the study area approximately took 45 minutes. Besides, 10 key informants selected from each tourism stakeholder had participated in focus group discussion conducted in Bahir Dar, the region's capital. The focus group discussion held in Bahir Dar lasted 3 hours. Overall, 37 research participants working in the area of tourism and hospitality were selected. An important aspect of qualitative research is reaching saturation loosely, a point at which observing more data will not lead to discovery of more information related to the research questions (Andrew et al., 2018). The author observed data and similar instances over and over again to be confident that information obtained from research participants are saturated. Thus, descriptions of information were thick and a theory would emerge (Bowen 2008). 
Table 1: Categories of respondents and Size

\begin{tabular}{|c|c|c|c|c|}
\hline No. & $\begin{array}{l}\text { Name of the company } \\
\text { /institution that respondents are working/ }\end{array}$ & $\begin{array}{l}\text { Interview } \\
\text { codes }\end{array}$ & $\begin{array}{l}\text { Number of } \\
\text { interviewees }\end{array}$ & $\begin{array}{l}\text { Number of focus } \\
\text { group discussants }\end{array}$ \\
\hline 1 & Academics & $\begin{array}{l}\mathrm{AC}_{1} \\
\mathrm{AC}_{2} \\
\mathrm{AC}_{3} \\
\mathrm{AC}_{4} \\
\mathrm{AC}_{5}\end{array}$ & 5 & 2 \\
\hline 2 & Travel agency business & $\begin{array}{l}\mathrm{TA}_{1} \\
\mathrm{TA}_{2} \\
\mathrm{TA}_{3} \\
\mathrm{TA}_{4}\end{array}$ & 4 & 1 \\
\hline 3 & Tour operation business & $\begin{array}{l}\mathrm{TO}_{1} \\
\mathrm{TO}_{2} \\
\mathrm{TO}_{3} \\
\mathrm{TO}_{4} \\
\mathrm{TO}_{5} \\
\mathrm{TO}_{6}\end{array}$ & 6 & 2 \\
\hline 4 & Hotel business & $\begin{array}{l}\mathrm{HO}_{1} \\
\mathrm{HO}_{2} \\
\mathrm{HO}_{3} \\
\mathrm{HO}_{4} \\
\mathrm{HO}_{5}\end{array}$ & 5 & 2 \\
\hline 5 & Local government tourism bureau & $\begin{array}{l}\mathrm{TB}_{1} \\
\mathrm{~TB}_{2} \\
\mathrm{~TB}_{3} \\
\mathrm{~TB}_{4} \\
\mathrm{~TB}_{5} \\
\mathrm{~TB}_{6} \\
\mathrm{~TB}_{7}\end{array}$ & 7 & 3 \\
\hline & & & 27 & 10 \\
\hline \multicolumn{2}{|r|}{ Total number of research participants } & \multicolumn{3}{|c|}{37} \\
\hline
\end{tabular}

\subsection{Data analysis}

All interviews and focus group discussion conducted within the study area were audio taped and transcribed. Transcriptions emanated from interviews and FGD were analysed through constant comparative method (Creswell, 2013). Data analysis was also frequentative with data collection. The collected data had been analysed as they were collected through the process of coding (Creswell, 2013). Through open coding, common themes associated to tourism investments were identified and examined to the context, meanings, and circumstances of the current tourism investment experiences of the study area. Besides, interviews were coded by conceptualizing and underlying patterns in the data. The main concepts of the present study involve how the major challenges affect tourism investment and how opportunities are vital to boost tourism investments in the study area. The patterns of the study chiefly stipulate the fundamental problems that inhibit tourism investments. Besides, the basic opportunities that support tourism investments are also outlined in the study area. On the other hand, initial data analysis processes were guided further and more focused on data collection which leads to further conceptualization of data and refinement of the coding schemes (Lewis \& Silver, 2007). Information is also created via clustering the compiled codes together (Glaser, 1993; Creswell, 2013). For the present study, conceptual saturation was reached whenever no new categories were generated (Charmaz, 2014). Moreover, theoretical memos were written throughout the coding process to track conceptual decisions and ideas as they were occurring (Masson, 2010). The author confirmed credibility of the data through using the techniques of persistent observation, peer debriefing such as presenting analyses to other experts to clarify the meanings and the basis for interpretations, and showing the analysis of the facts to informants for confirmation.

\section{Results and discussion}

\subsection{Analysis of tourism investments in Amhara region through Porter's five forces}

\subsubsection{Threats of new entrants}

According to Porter (2008), new entrants in an industry bring new capacity. Hence, Yunus and Indrasari (2017) asserted that the degree of the threat bank on the barriers to a certain industry producing many products. In fact, 
the higher the barriers to entry, the smaller the threat for existing players will be (Dobrivojević, 2013). Barriers to entry in any type of industries include the need for economies of scale, high customer loyalty for existing brands, large capital requirements, and the need for cumulative experience, government policies, and limited access to distribution channels (Porter, 1979). Likewise, in Amhara region, these factors deter the growth of foreign tourism investment. On the other hand, some tourism organizations working within Amhara region often compete to win the same market share (Teshome et al., 2018). That, in turn, affects tourism investment in the study area. Pertaining to the issue of tourism investment, threats of new entrants influence investors in a different extent (Porter, 1979). For instance, it is easy to launch a restaurant business in the study area. Thus, investors in restaurant business are expected to do more to survive within the industry since new entrants can simply join to the sector. However, in Amhara region, there are low threats of new entrants for those who need to invest their money on large star hotels providing various products and services. Hence, it is a viable option for large companies to invest in star hotels in Amhara region. On the other hand, threat of new entrant is high to enter into tour and travel businesses in the region as low amount of capital enables investors to simply join in these businesses (World Investment Report, 2011). In Amhara region existing tour companies have done little to retaliate; did not have patents, trademarks or did not have established brand reputation due to lack of clear understanding in managing tourism businesses and their poor performance to compete in the international market (Wondirad \& Ewunetu, 2018). Hence, tourism investors in Amhara region are strongly affected by the force of new entrants.

\subsubsection{Power of suppliers}

In Amhara region, different food and beverage service providers have created intense competition among suppliers. Therefore, food and beverage service providing institutions have weak power to attract buyers to their businesses because of the presence of various local food and beverage rendering organizations in the region (Meskele et al., 2016; Yunus \& Indrasari, 2017). Thus, weak power of suppliers in the food service sector would be a real challenge for new investors (Dobrivojevic, 2013). However, the bargaining power of suppliers in the airline industry and star hotel business is very high. Hence, businesses are to be in a better place when there is multitude of suppliers (Beirman, 2009). In the area of tourism investment, sources of supplier power encompass the switching costs of companies in the industry, availability of substitutes, the strength of their distribution channels and the level of differentiation in the product or services that the supplier is delivering (Porter, 1998; Meihami \& Karami, 2014). On the other hand, power of customers would also affect tourism investment as discussed below.

\subsubsection{Power of customers}

According to Porter (1980), buyers have a strong bargaining power when the industry consists of many small-scale businesses and many buyers. Indeed, buying power is low when customers buy products in a smaller quantity, act independently and when the seller's product is very different from any of its competitors. In the tourism and hospitality industry, customers can easily compare prices online, get information about wide variety of products and get access to products from other companies instantly (Adu-Ampong, 2017). Hence, the author believed that buyers in tourism and hospitality industry have high power in certain tourism products. For example, bargaining power of buyers in the airline industry is high. Customers are able to check prices of different airline companies through many online price comparison websites such as Skyscanner \& Expedia. Customers today are likely to fly with different carriers to and from their destination if that would lower the costs. Porter (2008) pointed out that companies can take measures to buyers' power by implementing loyalty programs or by differentiating their products and services. Thus, providing unique product would allow tourism and hospitality establishments to reduce threat of substitutes.

\subsubsection{Threat of substitutes}

Tourism and hospitality products serve similar needs raised from customers (Meihami \& Karami, 2014). Hence, investors in the field should take this into account while providing tourism products to the customers. In the context of tourism, nature based destination like Semain Mountain is usually not considered as a competitor of manmade attraction such as Lalibela (Porter, 1979; Endalkachew et al., 2018; Wondirad, 2018). However, since both Semain Mountain and Lalibela fulfil a similar need (i.e. getting relaxation); customers might be willing to switch from one to another if they feel that prices increase too much in either nature based or manmade attractions (Dobrivojevic, 2013; Meskel et al., 2017). This will ultimately affect tourism industry's profitability and should also be taken into consideration when evaluating the industry's attractiveness (Beirman, 2009).

\subsubsection{Rivalry among existing competitors}

Rivalry among firms shows the intensity of the current competition in the marketplace, which is determined by the number of existing competitors. Indeed, rivalry is high when a lot of competitors that are roughly equal in size and power are found in a given market. When the industry is growing slowly and when consumers can easily switch to a competitors offering for little cost, rivalry among firms would be happened (Porter, 1979; Buhalis, 2000). Hence, when rivalry is high, competitors are likely to actively engage in advertising and price wars, which can hurt a business's bottom line (Porter, 2008). The very significant opportunity in Amhara region is the presence of little rivalry among existing competitors in tour operation, travel agency and hotel businesses that did not have enough power to compete each other. The presences of a considerable number of tourist sites and few tourism 
businesses indicate that Amhara region is a viable investment area for both domestic and foreign investors.

\subsection{Challenges of tourism investment}

\subsubsection{Inadequate government structure in tourism}

Despite tourism needs a well-structured system, Amhara region has failed to devise an organized government structure in the field of tourism $\left(\mathrm{AC}_{1}\right.$, March 2019). Due to this reason, tourism and hospitality investments have not been properly managed for long. Tourism investment regulations in Amhara region was formulated without considering the current tourism potentials and challenges of $\left(\mathrm{TB}_{4}\right.$, April 2019). This condition impedes the growth of tourism sectors in the region (Yunus \& Indrasari, 2017). In line with this, an expert working in tour operation business $\left(\mathrm{TO}_{3}\right.$, May 2019) portrayed that lack of well-organized rules and regulations in tour operation business hamper the development of tourism industry in Amhara region. On the other hand, the author conceived that local government in tourism was not also in a position to give clear-cut responsibilities for those involving in travel agency and tour operation business. In accordance to this, Bishop (2010) and Montero (2011) ascertained that tour and travel companies should embolden tourism activities in tourist receiving areas. Distinctly, local government bodies should encourage tourism businesses in developing destinations.

On the other hand, the head of local government tourism bureau ( $\mathrm{TB}_{5}$, December 2018) outlined that tourism business investment in Amhara region is vital to support local agrarian societies through creating new market to agricultural products such as vegetables, meat and cereals. Nevertheless, the presences of inadequate government structure in the field of tourism ruin the development tour operation business, travel agency business and hotel investments in Amhara region. In accordance with this, Butler (1980) outlined that adequate government structure and the involvements of all tourism stakeholders specially travel agents and tour operators would foster tourism activities in emerging destinations. Unless government provides strong organizational structure in the field of tourism business, emerging destinations would not be frequented by a considerable number of visitors (Butler, 1991; Fesha, 2019; Goeldner \& Brent Ritchie 2009; UNWTO, 2018; Walter, 2017).

\subsubsection{Lack of infrastructural development}

Tourism infrastructure is ideal to attract tourists to a particular destination (UNWTO, 2018). The major tourism infrastructures embody transportation, public facilities, hotels, restaurants, travel agencies and banks. Thus, tourist destinations should emphasis on providing tourist infrastructures. Nonetheless, Amhara region was not in a good position to provide a comprehensive infrastructure for investors in tourism (ANRSCTB, 2018). Regarding tourism infrastructures, an expert in travel agency business $\left(\mathrm{TA}_{1}\right.$, February 2019) pointed out that Amhara region has failed to convey harmonized planning to develop infrastructures in potential tourist sites for the last two decades. Likewise, an owner of tour operation business $\left(\mathrm{TO}_{3}\right.$, May 2019) reaffirmed that tourists in the study area were not willing to experience tourist destinations outside the four main destinations namely Bahir Dar, Gondar, Semain Mountain National Park and Rock Hewn Church of Lalibela. This is due to lack of adequate infrastructures in other potential tourist sites such as Wanzaye Hot Spring and Guna Mountain. In accordance with this, Endalkachew et al. (2018) ascertained that tourism investment in potential tourist sites in Amhara region was poor due to fragmented infrastructural development. In fidelity, tourist destinations found at the remote areas of the region are mainly open for tourists who are adventure lovers such as mountain biking and rafting, but it would be more interesting if infrastructure is provided adequately and comfortably (FGD, June 2019). Furthermore, an integration of infrastructure must involve stakeholders in public work agencies, tourism agencies, activists and other community tourism initiatives (Zhang et al., 2006; Yunus \& Indrasari, 2017; Worku \& Tesema, 2018). On the other hand, an owner from one of the travel agency businesses mentioned that:

There will be no tourism investment without infrastructures. In fact, Amhara region was not able to attract foreign investors in tourism due to lack of infrastructures such as health, transportation, banking services, electricity, telecommunication and hotel services within potential tourist sites ( $\mathrm{TA}_{4}$, April 2019).

Moreover, according to an academician ( $\mathrm{AC}_{4}$, May 2019), a successful tourism destination development is contingent on all parts of the tourism products such as attractions, accommodation, transport, provided by public and private sector investment. Moreover, as quoted by a tourism expert working in government tourism bureau:

Tourism investment requires public infrastructures such as transportation, energy, water supply, and waste disposal system. In addition to public infrastructures, around and within potential tourist sites, there must be tourist infrastructures and facilities such as accommodation, restaurants, travel and tour services, shopping, recreations, health facilities. In the context of emerging destinations like Amhara region impoverished public and tourist infrastructures obstruct the development of tourism investment ( $\mathrm{TB}_{4}$, August 2019).

\subsubsection{Media information}

According to the viewpoints of a respondent working in one of the tour operation businesses ( $\mathrm{TO}_{5}$ August 2019), involving Media is fundamental to offer a great deal of information with respect to tourism investment potentials of many nations. However, in the context of Amhara region Medias did not contribute a lot in delivering 
information regarding tourism investment potentials of the region. On the other hand, an academician $\left(\mathrm{AC}_{2}\right.$, June 2019) teaching at Bahir Dar University (one of the most reputable universities in Ethiopia) pointed out that the role of regional radios and television in releasing tourism and hospitality related information were not sufficient. Besides, printed materials such as newspapers, magazines and brochures found in different information center do not also contain much information about tourist attractions and investment potentials. In fact, Media has played a vital role for the development of tourism and hospitality in potential tourist sites (Teka, 2016). Media is an important stakeholder in promoting opportunities of tourism investment in emerging destinations. However, Medias working in Amhara region did not focus on exploring and promoting tourism destinations which are essential for tourism investment (Teka, 2016; ANRSCTB, 2018). The author suggested that information about tourism investment is necessary to develop complete and adequate foreign and domestic tourism investment guidelines. Nonetheless, an expert working in government tourism bureau ( $\mathrm{TB}_{4}$, March 2019) portrayed that the Media sector was not extensively working towards facilitating the free flow of information about extant tourism resources that draw immense investment potentials. Hence, potential domestic and foreign investors were not in a place to get a complete picture of tourist destinations comfortable for tourism investment (Mcphead, 2011). In this notion, it is true that information related to tourist attraction in Amhara region was very low and did not impart any detailed issues useful to guide tourism and hospitality business investors (FGD, June 2019). Overall, absences of private and public Medias in the field of tourism partly restrain tourism investment in Amhara region.

\subsubsection{Improper land use policy}

According to an expert from government tourism bureau ( $\mathrm{TB}_{2}$, May 2019), tourism investment requires a suitable land use policy. Amhara region, however, has failed to devise proper land use policy due to lack of modern technologies that support land management approaches. Bureaucratic system and corruption also aggravated the poor land use policy of the government in the study area (FGD, June 2019). According to the owner of one of the travel agent business working in the study area (TA4, July 2019), government bodies in tourism shall have strategies to support local agrarian communities who have been losing their agricultural land for tourism and hotel investments. Unless the government does offer valuable things to farmers, the life of the rural people would be threatened. Therefore, any tourism and hospitality investment initiatives ought to be done in such a way that agrarian societies are benefited $\left(\mathrm{AC}_{1}\right.$, June 2019). Since local agrarian societies are owners of land suitable to agriculture, it was elusive to find land for tourism investment in Amhara region (Mao et al, 2009). This is because of the fact that local communities lead their life through farming and animal raising (ANRSCTB, 2018). Hence, farmers were not willing to lose their land for tourism investment (HO, March 2019). That, in turn, deprives tourism investment in Amhara region. Besides, local government bodies were not also capable enough to give benefits for local communities who are willing to give their lands for tourism investments (FGD, June 2019). In the meantime, local people are reluctant to offer their lands to potential domestic and foreign investors (Pearce, 2001, Worku \& Tessema, 2018). In summary, due to lack of prudent land management, tourism investment has not been facilitated in Amhara region (ANRSCTB, 2018). It is also quite obtrusive to understand the perception of the people about tourism investment within the region. In order to manage land resources in tourist destinations, public participation in each stage of tourism development is very critical since local people are cornerstones in tourism development (Alubel, 2010).

\subsection{Tourism investment opportunities in Amhara region}

\subsubsection{Availability of abundant natural and cultural attractions}

Tourism is the sum total of attractions, transportation and accommodation along with other tourist amenities and facilities (UNWTO, 2018). Among these elements, attraction is the foundation ingredient in all tourism related activities. Amhara region is rich in both natural and cultural tourism resources which are quite instrumental for tourism investment. For instance, Lake Tana which is located very close to Bahir Dar (the region's capital) is vital for tourism investments. It attracts investors that would like to invest on resorts and lodges (ANRSCT, 2018). There are only limited resorts operating around Lake Tana such as Dessiet Lodge, Grand Resort, Blue Nile Resort and Kuriftu Resorts providing limited hospitality service in the region. That calls another investment in the field of tourism and hospitality. Moreover, a key informant from government tourism bureau (TB 2, July 2019) pointed out that religious tourism is highly pronounced in cultural sites in Amhara region. Among tourist destinations, Gondar and Lalibela are the two popular religious sites ideal for pilgrimage travellers (Meskel, 2016; Wondirad \& Ewnetu, 2018). Apparently, people in the region often travel to these religious sites for pilgrimage purpose. Hence, it is a good opportunity for travel organizers to arrange tours to these religious sites and broaden their business (FGD, June 2019). Regarding the role of attractions in boosting tourism investments, the following quote is from an academician working at university level:

In my view, tourism resource identification should have to be a prime agenda for the development of tourism investment in Amhara region. Since natural and cultural attractions are cornerstones in capacitating tourism activities, emerging destinations should bring pleasant environments to the visitors ( $\mathrm{AC}_{4}$, June 2019). 
On the other hand, good climatic condition, astounding land feature, wide variety of endemic mammals and birds, mountainous areas and deep gorges are crucial for tourism investment in Amhara region. Distinctly, the region is a home to four national parks namely Semain Mountain National Park, Altash National Park, Bahir Dar Blue Nile Park and Borena Saynet National Parks. In fact, these parks play a pivotal role in tourism investment (Andereck et al., 2005; Alubel, 2010; Albertech, 2018). Thus, emerging destinations like Amhara region ought to explore its potentials and promote wise utilization of resources for future generations.

\subsubsection{Import policy of the government}

Tourism investment is a capital intensive investment that demands strong financial power. As a result, potential investors in tourism need to get support from the government. Even though local raw materials are abundantly found in the study area, equipment and materials that are not produced within the region are costly to run tourism businesses $\left(\mathrm{HO}_{4}\right.$, August 2019). Due to this reason, local and national governments give import duty-free for local investors. Hence, domestic investors in the field of tourism and hospitality import various items from an international market. For instance, investors in tour and travel business can import vehicles with no duty (Federal Democratic Republic of Ethiopia Ministry of Culture and Tourism, 2018; Ethiopian Tourism Organization, 2018). This circumstance would attract new entrants in the travel business (Porter, 1979; ANRSCTB, 2018). Investors in hotel business can import vehicles, large equipment, beds, tables, chairs, clothes and equipment with no import tax. Thus, duty free policy implemented by the government has played a very critical role in encouraging local investors in tourism businesses. The author also stressed that tourism investment in emerging destinations would be enhanced if government tourism bodies are in favour of local investors in the field.

\subsubsection{Availability of credit providing institutions}

Saving and credit providing institutions become crucial to enhance the economic and social advancement of many nations (UNWTO, 2018). Small and medium scale tourism enterprises need credit from financial institutions to expand their business (Bishop, 2010; Tamene \& Wondirad, 2019). In Amhara region, financial institutions like Amhara credit and saving institution provides credits to investors. Hence, this credit providing institution offers long-term loans to new entrants and existing tourism service providers. Domestic investors having limited capital could get money from this monetary institution (ANRSCTB, 2018). Pertaining to credit providing institutions and their roles in tourism investment, an owner of hotel businesses pointed out that:

For me, irrespective of the amount of money that investors need to have, credit providing institutions proposed a reasonable interest rate. Thus, credit providing institutions are quite important to meet investors' interest in expanding their businesses $\left(\mathrm{HO}_{3}\right.$, May 2019).

\section{Conclusion and implications}

The main intent of the present study was to examine the major opportunities of tourism investment in developing destinations. Identifying the good sides of tourism investment is vital to upgrade the development of tourist destinations. The current study also investigated the major challenges that deter the development of tourism investment in the context of Amhara region as an emerging destination. Porter's five forces industry analysis have been used to guide the study. Since the fundamental problems and opportunities of tourism investment are mentioned, findings of the current study are instrumental for destination management bodies to properly formulate tourism investment policies and guidelines in developing and newly emerging destinations.

Developing destinations in the continent of Africa should do robust work to meet the African tourism strategy of agenda 2063 (United Nations Conference on Trade and Development, 2017). Tourism is becoming an important sector in terms of its contribution to new job creation and improving gross domestic products in many countries of Africa (Spencelery \& Meyer, 2012; Yunus \& Indrasari, 2017). However, findings of the present study unfold that emerging destinations like Amhara region encountered convoluted problems in exploiting untapped tourism resources. Thus, to better harness the potential of tourism, Amhara region should adopt investment policies that boost interregional tourism and promote peace (Spencelery \& Meyer, 2012; UNCTD, 2017). Moreover, tourism opportunities need to get recognition by policymakers at national and regional levels (Meihami \& Karami, 2014). According to the viewpoints of an academician $\left(\mathrm{AC}_{2}\right.$, July 2019) policymakers in tourism shall deeply understand opportunities of tourism development and introduce strategies to cut constraints deterring tourism investment in Amhara region. Furthermore, all stakeholders in tourism including government, tour and travel companies, Media, hotel sectors and local communities should coordinate each other to develop tourism investment in the region. In order to improve tourism investment, government and private sectors shall emphasis on improving health care services and providing appropriate transportation facilities and developing general infrastructure in the region. Besides, joint ventures should also be advocated between local firms and international hotel operators, therefore, ownership and management of hotels would involve a mix of local and foreign capital (Adu-Ampong, 2017). This is very critical to reduce leakage in the economy. Overall, the tourism sector offers a promising avenue for boosting service exports for Amhara region (Worku \& Tesema, 2018). In general, the current study delineated that by applying the adopted Porter's five forces industry analysis, the study area is given an opportunity to see its place 
in the domestic and global tourism investment market (Dobrivojevic, 2013; Meskel et al., 2016).

\section{References}

Adu-Ampong, E.A. 2017. Divided we stand: Institutional collaboration in tourism planning and development in the Central Region of Ghana. Current Issues in Tourism, 20(3), 295-314.

AfDB (African Development Bank). 2016a. Africa Visa Openness Report.

Ajala, O.A. 2011. The regional impact of tourism development in the Amhara Region of Ethiopia. IFE Research Publications in Geography, 10(1).

Amhara National Regional State Culture and Tourism Bureau (ANRSCTB, 2018). Report on Tourist flow to Amhara National Regional State, Bahir Dar. Unpublished.

Andereck, K.L., Valentine,. K.M., Knopf, R.C., and Vogt, C.A. 2005. Residents' perceptions of community tourism impacts. Annals of Tourism Research 32(4): 1056-1076.

Arbache, J.S.,Blake, A., Sinclair., M.T., and Teles, V. 2008. Tourism and poverty relief. Annals of Tourism Research 35(1): 107-126.

Beirman, D. 2009. Tourism and the global economic crisis of 2008, Harvard Business Review, USA.

Bishop, M.L. 2010. Tourism as a small-state development strategy: Pier pressure in the Eastern Caribbean? Progress in Development Studies 10(2), 99-114.

Boesen, M., Sundbo, D., and Sundbo, J. 2017. Local food and tourism: An entrepreneurial network approach. Scandinavian Journal of Hospitality and Tourism. doi:10.1080/15022250.2016.1218629.

Bowen, G.A. 2008. Naturalistic inquiry and the saturation concept: a research note. Qualitative Research 8(1), 137-52.

Brau, R., Lanza, A., and Pigliaru, F. 2007. How fast are small tourism countries growing? Evidence from the data for 1980-2003. Tourism Essentials 13(4, 603-613.

Buhalis, D. 2000. Marketing the competitive destination of the future. Tourism Management, 2(1), 97-116.

Butler, R.W. 1991. Tourism, environment, and sustainable development. Environmental Conservation 18(3), 201209.

Charmaz, K. 2014. Constructing ground theory: A practical guide through qualitative analysis. Thousand Oaks, CA: Sage.

Chou, M.C. 2013. Does tourism development promote economic growth in transition countries? A Panel Data Analysis, Economic Modeling 33: 226-232.

Coulter, M.2010. Strategic Management in Action, 4th ed. Belgrade, Data status, 2010. Serbian.

Coxhead, I., \& Wattanakuljarus, A. 2008. Is tourism-based development good for the poor? A general equilibrium analysis for Thailand. Journal of Policy Modelling 30: 929-955.

Creswell, J.W. 2013. Research Design: Qualitative, quantitative and mixed methods approaches. Los Angeles, CA: Sag publication.

Degarege, A.G., and Lovelock, B. 2018. Sustainable tourism development and food security in Ethiopia: Policy Making and Planning. Tourism planning and development. Retrieve on http://doi.org/10.1080/21568316.20181528565.

Dobrivojević ,G. (2013). Analysis of the competitive environment of tourist destinations aiming at attracting FDI by applying Porter's Five Forces Model. British Journal of Economics, Management and Trade 3(4), 359371.

Dritsakis, N. 2012. Tourism development and economic growth in seven Mediterranean countries: A panel data approach. Tourism Economics 18(4), 801-816.

Ernoul, L. 2009. Residents' Perception of Tourist Development and the Environment: A Study from Morocco. International Journal of Sustainable Development \& World Ecology 16(4), 228-33.

Goeldner, C.R., and Brent-Ritchie, J.R. (2009). Tourism: Principles, practices, philosophies (11th ed.) Hoboken, NJ: John Wiley \& Sons.

Gursoy, D., and Denney, R. 2004. Host attitudes toward tourism, an improved structural model. Annals of Tourism Research 31(3), 495-516.

Jithendran, K.J., \& Baum,T. 2000. Human Resources Development and Sustainability the Case of Indian Tourism, Glasgow: John Wiley \& Sons Ltd.

Kebete, Y., and Wondirad, A. 2019. Visitor management and sustainable tourism destination development nexus in Zegie Peninsula, Northern Ethiopia. Journal of Destination Marketing \& Management 13, 83-98.

Kidane-Mariam, T.2015. Ethiopia: Opportunities and challenges of tourism development in the Addis Ababaupper Rift Valley Corridor. Journal of Tourism \& hospitality 4, 167. doi:10.4172/21670269.1000167

Lepp, A. 2007. Residents' attitude towards tourism in Bigodi Village, Uganda. Tourism Management 28(3), 876885.

Lewins, A., and Silver, C. 2007. Using software for qualitative data analysis, London: Sage Publications.

Lowe, A., Norris, A.C., Farris, J., and Babbag, D.R. 2018. Quantifying thematic saturation in qualitative data 
analysis. Field Methods, 30(3): 191-207.

Mason, M . 2010. Sample size and saturation in $\mathrm{PhD}$. Studies using qualitative interview. Forum, Qualitative Sozial Forschung/ forum: Qualitative social research 11 (3).

Mcphead, S. 2011. Developing an internet marketing strategy: internet marketing academy and Ventus publishing Aps. Downloaded the free book at bookboon.com. Available at: www.internetmarketingacademy.comlast.

Meihami, B., \& Karami, J. 2014. Review some effects of the investment in the tourism sector (Evidence of the Qhorveh City), International Letters of Natural Sciences 25:39-46.

Meskele, A. 2016. The Historic Route in Ethiopian Tourism Development. African Journal of Hospitality, Tourism, and Leisure 5(2): 1-13.

Montero, C.G. 2011. On tourism and the constructions of Paradise Islands in Central America and the Caribbean. Bulletin of Latin American Research, 30(1): 21-34.

Odhiambo, N.M. 2011. Tourism development and economic growth in Tanzania: Empirical evidence from the ARDL bounds testing approach. Economic Computation and Economic Cybernetics Studies and Research, 3 .

Pearce, D.G. 2001. Tourism and urban land use change: Assessing the impact of Christchurch's tourist tramway. Tourism and Hospitality Research 3(2). Sage Publications, Ltd.

Pearse, N.J. 2009. The role of experiences in creating and developing intellectual capital. Management Research News 32 (4): 371-372.

Poon, A. 1989. Competitive strategies for a new tourism. In progress in tourism, recreation and hospitality management, edited by C. P. Cooper, 91-102. Belhaven Press.

Poon, A. 1993. Tourism, Technology and Competitive Strategies. C.A.B. International.

Porter, M.E. 1998. Competitive advantage: creating and sustaining superior performance: with a new introduction, New York, The Free Press; 1998.

Porter, M.E. 2008. The Five Competitive Forces That Shape Strategy. Harvard Business Review. Available at: http://hbr.org/2008/01/the-five-competitive-forces-that-shape-strategy/

Rasul, G., and Manandhar, P. 2009. Prospects and Problems in Promoting Tourism in South Asia: A Regional Perspective. South Asia Economic Journal 10(1), 187-207.

Reid, D.G .2003. Tourism, Globalization and Development: Responsible Tourism Planning. Pluto Press London.

Robaina-Alves, M., Moutinho, V., and Costa, R. 2016. Change in energy-related CO2 (carbon dioxide) emissions in Portuguese tourism: A decomposition analysis from 2000 to 2008. Journal of Cleaner Production 111, 520-528.

Roe, D., Ashley, C., Page, S., and Meyer, D. 2004. Tourism and the poor analyzing and interpreting tourism statistics from a poverty perspective.

Rogerson, C.M. 2015. Tourism and Regional Development: The Case of South Africa's Distressed Areas. Development Southern Africa, 32(3): 277-91.

Signe, L. 2018. Africa's tourism potential Trends, drivers, opportunities, and strategies.

Spenceley, A., and Meyer, D. 2012. Tourism and poverty reduction: Theory and practice in less economically developed countries. Journal of Sustainable Tourism, 20(3): 297-317.

Swain, S.K. 2006. Human resource development in tourism: Principles and Practices, New Delhi: Abhijeet Publications.

Teka, M.K. 2016. The role of media in tourism promotion: A case study in Ethiopia. Journal of Hospitality Management and Tourism 7(5), 50-56.

United Nations Conference on Trade and Development (2017). Economic Development in Africa Report 2017: Tourism for Transformative and Inclusive Growth.

United Nations Development Program (2011). Tourism and Poverty Reduction Strategies in the Integrated Framework for Least Developed Countries.

WNCTD (2017). Economic development in Africa: Tourism for transformative and inclusive growth.

Wondirad, A. 2019. Retracing the past, comprehending the present and contemplating the future of cruise tourism through a meta-analysis of tourism journal publications. Marine Policy 108:1-14.

World Bank (2017). Ethiopia overview. Retrieved from http://www.worldbank.org/en/country/

World Economic Forum (2017). The Travel \& Tourism Competitiveness Report 2017: Paving the Way for a More Sustainable and Inclusive Future.

World Investment Report (2011). Non-Equity Modes of International Production and Development, United Nations New York and Geneve, 2011

Yunus, E., \& Indrasari, M. 2017. Opportunities and Challenges of Tourism Industry. International Journal of Economic Research 14(7).

Zhang, J., Inbakaran, R.J, and Jackson ,M. 2006. Understanding community attitudes towards tourism and hostguest interaction in the urban-rural border region. Tourism Geographies, 8(2): 182-204. 